\title{
Creative use of a sutureless valve
}

\author{
Craig R. Smith, MD
}

\footnotetext{
From the Department of Surgery, Vagelos College of Physicians \& Surgeons of Columbia University, Columbia University Irving Medical Center of New York Presbyterian Hospital, New York, NY. Disclosures: Author has nothing to disclose with regard to commercial support.

Received for publication July 26, 2018; accepted for publication July 26, 2018; available ahead of print Aug 29, 2018.

Address for reprints: Craig R. Smith, MD, Columbia University Irving Medical Center of New York Presbyterian Hospital, Milstein Building 7-435, 177 Fort Washington Ave, New York, NY 10032 (E-mail: crs2@cumc. columbia.edu).

J Thorac Cardiovasc Surg 2019;157:229-30 $0022-5223 / \$ 36.00$

Copyright (C) 2018 by The American Association for Thoracic Surgery https://doi.org/10.1016/j.jtcvs.2018.07.084
}

Szczechowicz and colleagues ${ }^{1}$ describe an intriguing out-of-the-box application of a sutureless aortic bioprosthesis (Perceval; LivaNova, London, United Kingdom) to manage annular abscesses in mitral endocarditis. The authors tricked-out the stock product by clipping off the outflow portion of the nitinol frame with sternal wire cutters, then suturing the inflow rim of what the manufacturer calls the inflow ring or the sealing collar to a pleat of the left atrium, outside the annulus. A major objective was to avoid suturing patch material into friable tissue, which is often done to facilitate conventional valve replacement. Underpinning the conventional patch approach is a belief that the patch will be pressed into the cavity during systole, obliterating dead space and preventing erosion of friable tissue by pressurized blood. Such patches are sutured to relatively healthy muscle on the left ventricle side of the defect, which should prevent pressurized blood from getting underneath the patch during systole.

The technique presented here simply applies the valve sealing collar to surrounding tissue without suturing at the outflow end, leaving a free edge but relying on the compressive radial force generated by expansion of the nitinol frame within the collar to seal the space between the free edge (the supra-annular cuff) and the suture line. Although securely sutured at the inflow end, it seems conceivable that pressurized blood could be driven from the left ventricle into the abscess cavities and into the potential space between the valve and surrounding tissue. That does not seem to be a problem when the valve is placed in the aortic position, but in that situation the valve is open during systole, not closed.

It is worth noting that the sealing collar on a Perceval XL is only $8 \mathrm{~mm}$ in length (Perceval Valve \& Accessories: Measurement References, page 5; unpublished internal document shared by LivaNova, 2015). With its inflow edge sutured at least a few millimeters outside the annulus, the collar might cover some of the annulus, but seems unlikely to cover subannular abscesses. Perhaps that does

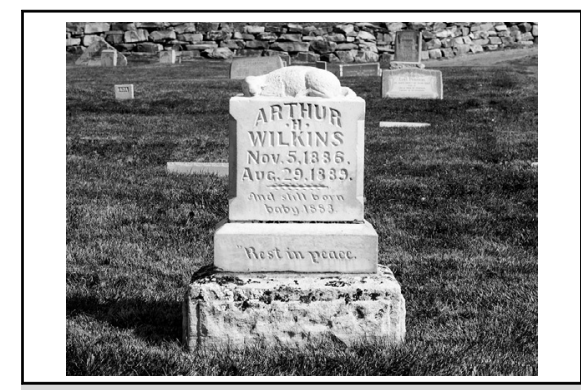

Changing the discharge plan for endocarditis

Central Message

A modified aortic bioprosthesis may improve conventional methods for treating invasive mitral endocarditis and severe mitral annular calcification

See Article page 225 .

not matter. There are numerous descriptions of very similar techniques $^{2-6}$ in which a prosthesis is sutured into the left atrium outside the annulus, embellished with a variety of reinforcements using felt ${ }^{5}$ or plicated leaflet tissue. ${ }^{4}$ When used in severe mitral annular calcification (MAC) the annulus is usually left intact, in which case pressure erosion of cavities is less likely, but left atrial implantation has also been described in severe erosive endocarditis. ${ }^{5,6}$ Published precedents need to be interpreted with caution because there is inherent broad variation in pathology, but they do suggest that covering every abscess cavity may not be essential.

Invasive endocarditis tests the sphincter tone of the best surgeons. The same is true of severe MAC, which is more common. Although patching an abscess or a calcium debridement cavity is the most common approach, that technique is undeniably time-consuming, and nowhere near $100 \%$ successful. A simple and effective alternative would be cause for rejoicing. Have Szczechowicz and colleagues $^{1}$ found that alternative? Hopefully, but we need to see how it works in patients who survive longer than 25 days. Even pending that, it is easy to imagine how this contribution might simplify variations on existing options. If it works for endocarditis, it might work even better for severe MAC, which would significantly expand the niche for this technique. That would give the Perceval valve at least 1 reason for being, providing some solace for advocates of sutureless valves in their Quixotic quest to hold back the transcatheter aortic valve replacement tsunami. 


\section{References}

1. Szczechowicz M, Mashour A, Chaduneli O, Weyman A. Implantation of Perceval valve in mitral position: a new technique. J Thorac Cardiovasc Surg. 2019;157: 225-8.

2. Uchimuro T, Fukui T, Shimzu A, Takanashi S. Mitral valve surgery in patients with severe mitral annular calcification. Ann Thorac Surg. 2016;101:889-95.

3. Atoui R, Lash V, Mohammadi S, Cecere R. Intra-atrial implantation of a mitral valve prosthesis in a heavily calcified mitral annulus. Eur J Cardiothorac Surg. 2009;36:776-8
4. Di Stefano S, Lopez J, Florez S, Rey J, Arevalo A, San Roman A. Building a new annulus: a technique for mitral valve replacement in heavily calcified annulus. Ann Thorac Surg. 2009;87:1625-7.

5. Sakamoto S, Matsubara J, Nagayoshi Y, Nishizawa H, Takeuchi K, Kiyosawa J. Annular reconstruction for mitral valve replacement in a destroyed or calcified mitral annulus. Jpn J Thorac Cardiovasc Surg. 2006;54:500-3.

6. Nataf P, Pavie A, Jault F, Bors V, Cabrol C, Gandjbakhch I. Intraatrial insertion of a mitral prosthesis in a destroyed or calcified mitral annulus. Ann Thorac Surg. $1994 ; 58: 163-7$ 